\title{
INTRODUKSI PEMANFAATAN LEGUM Indigofera zollingeriana SEBAGAI PENGGANTI SEBAGIAN KONSENTRAT PADA SAPI POTONG DI KELOMPOK PETERNAK PUTRA NUSA, DESA KONDANGDJAJA, KECAMATAN CIJULANG, KABUPATEN PANGANDARAN
}

\author{
Novi Mayasari, dan M. Rifqi Ismiraj \\ Fakultas Peternakan, Universitas Padjadjaran, Sumedang, Jawa Barat \\ E-mail: novim001@gmail.com
}

\begin{abstract}
ABSTRAK. Wawasan peternak terhadap kebutuhan nutrien merupakan hal yang penting dalam peningkatan produktivitas ternak. Salah satui penyebab utama rendahnya ketersediaan nutrisi di dalam pakan dalam usaha pembibitan sapi potong di Indonesia adalah wawasan peternak akan manajemen pakan. Hal ini dapat berdampak pada terganggunya sistem pertahanan tubuh dan menurunnya tingkat produktivitas ternak. Pakan merupakan salah satu komponen penunjang utama dalam produksi peternakan dikarenakan $60-70 \%$ biaya produksi berasal dari pakan. Salah satu usaha untuk meningkatkan kandungan nutrisi dalam pakan lengkap untuk sapi perah adalah dengan mencari bahan pakan alternatif. Indigofera zollingeriana berpotensi untuk menjadi bahan pakan alternatif karena selain kandungan proteinnya yang tinggi (27,9\%) juga dilengkapi oleh kandungan mineral kalsium $(0,22 \%)$ dan fosfor $(0,18 \%)$. Informasi ini dirasa perlu untuk dibagikan kepada masyarakat. Desa Kondangdjaja, Kecamatan Cijulang, Kabupaten Pangandaran adalah wilayah yang memiliki populasi sapi potong yang cukup signifikan di Kabupaten Pangandaran, Jawa Barat. Sebagai bentuk pembagian informasi, maka dilakukanlah kegiatan penyuluhan introduksi terhadap potensi manfaat Indigofera zollingeriana sebagai hijauan sumber protein pengganti sebagian konsentrat sapi potong di daerah tersebut. Tujuan dari kegiatan penyuluhan ini adalah meningkatkan pengetahuan peternak mengenai potensi manfaat Indigofera zollingeriana sebagai bahan pakan alternatif hijauan pengganti sebagian konsentrat. Kegiatan penyuluhan berhasil dilaksanakan dengan mencapai target luaran yaitu peternak dapat menjelaskan potensi manfaat dan metode pengembang biakan Indigofera zollingeriana sebagai salah satu hijauan sumber protein alternatif pengganti sebagian konsentrat.
\end{abstract}

Kata kunci: Indigofera zollingeriana; konsentrat; hijauan sumber protein alternatif; penyuluhan introduksi; sapi potong

ABSTRACT . Knowledge about nutrient requirements for livestock is an important factor for the farmer to increase their livestock productitivity. One of the primary causes of the low availability of nutrients in feed in beef cattle breeding farms in Indonesia is the knowledge of the farmer about feed management. This fact can have an impact on the disruption of the body's defense system and declining levels of productivity of livestock. Feed is one of the main supporting components in livestock production because 60-70\% of production costs come from the feed. One effort to increase the nutrient content in complete feed for beef cattle is to look for alternative feed ingredients. Indigofera zollingeriana has the potential to be an alternative feed ingredient because not only it has high protein content $(27.9 \%)$ but also contained with calcium (0.22\%) and phosphorus (0.18\%). This information is deemed necessary to be shared with the public. Kondangdjaja Village in Cijulang District is a region that has a significant beef cattle population in Pangandaran Regency, West Java. As a form of information sharing, introductory counseling activity was carried out to introduce the potential benefits of $\underline{\text { Indigofera }}$ zollingeriana as a source of substitute in beef cattle complete ration. The purpose of this introductory counseling is to increase farmers' knowledge about the potential benefits of Indigofera zollingeriana as an alternative feed ingredient that is rich in protein. Introductory counseling activity were successfully carried out by achieving the output target in which farmers can explain and apply the potential benefits and methods of breeding Indigofera zollingeriana as one of the alternative forage feed ingredients.

Key words: Indigofera zollingeriana; complete ration; alternative protein source forage; introductory counseling; beef cattle.

\section{PENDAHULUAN}

Kelompok Peternak Putra Nusa (KPPN) adalah salah satu kelompok peternak yang berlokasi di Desa Kondangdjaja, Kecamatan Cijulang, Kabupaten Pangandaran. Tujuan utama KPPN adalah pembibitan dan perkembangbiakan sapi potong. Kegiatan utama di KPPN adalah melakukan perencanaan dan pelaksanaan perkembangbiakan sapi potong, kemudian dilakukan pemeliharaan dari lahir hingga mencapai umur yang mencukupi untuk digemukkan oleh pelaku usaha penggemukan. Secara kronologis, KPPN mendapatkan bantuan modal awal berupa bibit sapi potong sebanyak 70 ekor dari Pemerintah Provinsi Jawa Barat, lalu dilakukan pembagian bibit sapi potong kepada seluruh anggotanya. Jumlah anggota KPPN adalah sebanyak 35 orang, sehingga setiap orang dialokasikan memiliki 2 ekor sapi.

Permasalahan utama pada KPPN adalah rendahnya ketersediaan nutrisi di dalam pakan, dilatar belakangi oleh rendahnya wawasan para anggota peternak KPPN terhadap pengetahuan nutrien yang diperlukan oleh sapi potong. Sebagai contoh, pada tahap survei kami menemukan bahwa para peternak anggota KPPN hanya memberikan pakan berbasis jerami padi dan singkong, tanpa diberikan konsentrat. Hal ini membuat hewan rentan berada dalam status kekurangan nutrisi dan hal ini dapat menyebabkan terganggunya sistem pertahanan tubuh, reproduksi, dan menurunnya tingkat produktivitas ternak (Salgueiro, dkk., 2000; Tanaka, dkk., 2001). Terganggunya sistem pertahanan tubuh dapat mengakibatkan mudahnya ternak terserang penyakit, sedangkan menurunnya produktivitas akan berdampak kepada menurunnya produksi daging dan terganggunya proses reproduksi sapi potong (Bertoni, $d k k$., 2009), yang sangat vital dalam kegiatan usaha pembibitan. Selain itu, daya dukung pakan untuk menunjang kebutuhan hidup sesuai dengan tujuan 
pembibitan menjadi perhatian utama karena sebanyak 60$70 \%$ biaya produksi berasal dari pakan (Setiyatwan, $d k k$., 2018).

Salah satu usaha untuk meningkatkan nilai gizi dalam ransum untuk usaha pembibitan sapi potong ialah menggunakan bahan pakan alternatif yang memiliki salah satu komponen nilai gizi yang dominan. Bahan pakan alternatif berpotensi menjadi andalan ketika terjadi penurunan kualitas dalam bahan pakan utama seperti rumput dan konsentrat. Selain itu, bahan pakan alternatif juga berpotensi untuk menggantikan (substitusi) dan melengkapi (komplemen) bahan pakan utama yang tersedia. Lebih jauh lagi, bahan pakan alternatif biasanya bersifat memiliki harga yang lebih murah dibandingkan dengan bahan pakan utama, namun hanya memiliki salah satu komponen nutrisi yang dominan, sehingga penggunaannya memerlukan pencampuran dengan bahan pakan lain.

Indigofera zollingeriana merupakan tanaman legum yang berpotensi besar untuk menjadi bahan pakan alternatif sumber protein di dalam usaha produksi sapi potong. Akhir-akhir ini, Indigofera zollingeriana banyak dikembangkan karena memiliki produksi biomassa yang cukup tinggi dengan manfaat yang baik sebagai pengganti konsentrat dalam ransum sapi perah (Salman, $d k k$. 2017). Sirait, dkk. (2009) melaporkan leguminosa Indigofera zollingeriana memiliki rataan produksi hingga 63,57\% dari total produksi segar. Selain itu leguminosa Indigofera zollingeriana memiliki kandungan nutrien yang sangat baik antara lain protein kasar (PK) sebesar 27,9\%, serat kasar (SK) sebesar 15,25\% dan kandungan mineral yang cukup tinggi yaitu kalsium (Ca) $0,22 \%$ dan fosfor $0,18 \%$ (Akbarillah, $d k k$., 2002).

Lebih jauh lagi, Tarigan (2009) menyebutkan bahwa kandungan protein kasar, kalsium, dan fosfor dalam Indigofera zollingeriana tertinggi pada pemotongan pertama namun kandungan tersebut semakin menurun seiring dengan meningkatnya interval pemotongan. Hassen, dkk., (2006) melaporkan bahwa legum Indigofera zollingeriana selain memiliki kandungan protein yang tinggi, legum ini toleran terhadap musim kering, genangan air dan tahan terhadap salinitas, sehingga legum ini sangat potensial untuk dikembangkan hampir di berbagai wilayah Indonesia, bahkan di wilayah dekat pantai sekalipun, seperti Kabupaten Pangandaran. Hingga saat ini telah terdapat wilayah pembibitan Indigofera zollingeriana yang menjual tidak hanya bibit, namun juga benih dan tepung Indigofera zollingeriana di Kabupaten Pangandaran. Tarigan dan Ginting (2011) melaporkan bahwa pemanfaatan Indigofera zollingeriana dalam ransum kambing mampu meningkatkan kecernaan bahan kering (BK), bahan organik (BO), protein kasar, neutral detergent fiber (NDF) dan acid detergent fiber (ADF). Tingginya kecernaan dari legum ini diduga karena rendahnya kadar tanin dan tingginya kandungan protein.

Nilai tambah dari legum ini adalah tingginya kandungan mineral kalsium, fosfor, kalium dan magnesium
(Abdullah, 2014). Salman, dkk. (2017) melaporkan bahwa penggunaan legum Indigofera zollingeriana mampu menggantikan 2,92 kg/ekor/hari atau $15 \%$ konsentrat dalam ransum komplit tanpa memberikan dampak negatif pada konsumsi dan produksi susu. Umumnya hijauan di Indonesia rendah akan kandungan mineral, akan tetapi dengan tingginya kandungan mineral pada legum ini menjadi salah satu potensi hijauan yang berkualitas. Lebih jauh lagi, penggunaan Indigofera zollingeriana dengan rasio rumput gajah: Indigofera zollingeriana sebesar 40:60\% dapat meningkatkan bobot badan dan menurunkan konversi pakan ternak sapi potong (Nurhayu \& Pasambe, 2014).

Informasi ini dirasa perlu untuk dibagikan kepada masyarakat umum sebagai bentuk pengabdian kepada masyarakat. Di Jawa Barat, Kabupaten Pangandaran adalah salah satu wilayah yang memiliki populasi sapi potong terbesar yaitu sebanyak 15.376 ekor di tahun 2016 (BPS Jabar, 2017). Data tersebut mengindikasikan potensi yang tinggi dalam produksi sapi potong di Kabupaten Pangandaran. Salah satu kelompok pelaku usaha pembibitan dan peningkatan populasi sapi potong di Kabupaten Pangandaran adalah KPPN.

Setelah dilakukan survei dan wawancara langsung di KPPN, diperoleh informasi bahwa terdapat beberapa permasalahan yang berkenaan dengan aktivitas usaha pembibitan dan perkembangbiakan sapi potong, diantaranya: (1). Rendahnya wawasan anggota peternak KPPN terhadap komposisi nutrien (baik dari hijauan maupun konsentrat) yang dibutuhkan oleh sapi potong, dan (2). Harga bahan baku konsentrat yang semakin mahal dan aksesnya yang semakin sulit sehingga peternak memiliki kesulitan untuk memenuhi kebutuhan usaha pembibitan sapi potong.

Hal ini menjadi latar belakang dilaksanakannya aktivitas introduksi alternative sumber pakan hijauan berkualitas kepada peternak. Pemberikan informasi dan pengenalan tanaman legum yang berpotensi besar untuk menjadi alternatif dan substitusi untuk hijauan dan konsentrat yang mengalami penurunan akses dan peningkatan harga. Tujuan dilakukannya aktivitas introduksi ini adalah memperkenalkan dan meningkatkan pengetahuan peternak terhadap potensi manfaat Indigofera zollingeriana sebagai bahan alternatif hijauan untuk pakan sapi potong. Diharapkan, setelah dilaksanakannya pengabdian kepada masyarakat ini, peternak dapat mengetahui potensi Indigofera zollingeriana sebagai salah satu hijauan alternatif sumber protein sebagai pengganti sebagian protein untuk sapi potong, sehingga diharapkan dapat meningkatkan kesejahteraan peternak.

\section{METODE}

Pengabdian kepada masyarakat dilakukan dengan metode penyuluhan dengan tujuan introduksi potensi manfaat Indigofera zollingeriana sebagai bahan pakan 
alternatif. Informasi yang dimasukkan ke dalam program introduksi dan penyuluhan meliputi: (a). Pengenalan kategorisasi bahan makanan sapi potong; (b). Kebutuhan nutrisi sapi potong berdasarkan berbagai penelitian; (c). Prinsip perhitungan sederhana kebutuhan makanan dalam ransum sapi potong; dan (d). Pengenalan dan pemaparan mengenai karakteristik dan manfaat Indigofera zollingeriana sebagai tanaman legum potensial untuk menggantikan konsentrat.

Kegiatan survei, wawancana, penyuluhan disertai pelatihan singkat mengenai potensi manfaat Indigofera zollingeriana di KPPN dilaksanakan pada bulan AprilMei 2018. Kegiatan dimulai dengan wawancara melalui penjajagan, penyebaran kuesioner hingga dilakukannya penyuluhan dan pelatihan pembuatan ransum komplit menggunakan Indigofera zollingeriana. Kegiatan penyuluhan ini dihadiri oleh 12 anggota peternak KPPN dan 5 non-anggota peternak KPPN. Kehadiran non-anggota peternak KPPN merupakan salah satu indikasi bahwa antusiasme para peternak dan masyarakat yang sangat tinggi, meskipun tidak tergabung ke dalam KPPN. Beberapa anggota KPPN tidak dapat hadir dikarenakan peternak harus bekerja di tempat lain. Penyuluhan dilaksanakan dengan ceramah berdasarkan informasiinformasi yang telah disebutkan di atas. Selain itu, sebagai bentuk nyata pengenalan dan bentuk dorongan untuk memulai produksi Indigofera zollingeriana, dalam pertemuan penyuluhan juga dilakukan penyerahan bibit Indigofera zollingeriana kepada perwakilan pihak KPPN. Setelah dilakukan pendampingan, penyuluhan, dan pelatihan singkat, dilakukan tahap evaluasi yaitu dengan menilai indikator capaian berupa kemampuan peternak untuk memproduksi ransum komplit berbasis Indigofera zollingeriana.

\section{HASIL DAN PEMBAHASAN}

Tahap survei dilakukan untuk mengidentifikasi dan memilih kelompok peternak yang akan dijadikan wilayah pengabdian, dengan tahapan seperti yang telah dijelaskan dalam Susilawati $d k k$. (2014) dan Hernaman $d k k$. (2018)in particular to beef cattle have shown a good performance. This can be seen from the increase of beef cattle and buffalo populations at $7.34 \%$ based on census in 2013. The Markets of beef cattle in Purwakarta is hugely opened as its location is near to the Capital Province of Jakarta and is supported by a highway 'Tol' road that making the distribution easier. Nonetheless, the update condition shows that most farmers in Purwakarta are not feeding their cattle with a standard quality of diets. They are just depending upon low quality roughages. Feeding concentrate as an additional diet can be the solution to improve the cattle performances. Thus, a number of short trainings about how to formulate concentrate diet using local feed ingredients has been done for the farmers included: (1. Pemilihan kelompok ternak didasarkan kepada populasi ternak dan kondisi perkandangan. Berdasarkan tahap ini, berhasil diputuskan bahwa kegiatan pengabdian kepada masyarakat dilakukan di KPPN, dengan mempertimbangkan:

a. Populasi ternak potong yang cukup besar (jumlah ternak sapi potong 70 ekor).

b. Kondisi perkandangan yang cukup memadai.

Selain itu, tahap survei juga dilakukan untuk mengidentifikasi masalah yang terjadi pada kelompok peternak objek penyuluhan. Permasalahan yang berhasil diidentifikasi adalah:

a. Rendahnya pengetahuan anggota kelompok peternak akan kebutuhan nutrisi sapi potong, khususnya dengan tujuan pemeliharaan pembibitan. Hal ini menjadi penyebab mereka memberikan bahan pakan sekadarnya.

b. Sulitnya ketersediaan hijauan, sehingga harga hijauan menjadi tidak ekonomis.

c. Kondisi populasi ternak yang tidak optimal produksinya dan berada dalam status rentan terserang berbagai penyakit.

Berdasarkan masalah yang telah teridentifikasi maka dilakukan persiapan untuk menyusun jadwal dan materi penyuluhan. Simultan dengan itu, komunikasi dengan perwakilan KPPN juga terus dibangun dalam rangka penyampaian informasi mengenai Indigofera zollingeriana, serta sebagai tahap koordinasi untuk persiapan teknis acara penyuluhan yang akan dilakukan.

Tahap penyuluhan disertai pelatihan singkat dilaksanakan dengan cara ceramah mengenai potensi manfaat Indigofera zollingeriana. Materi penyuluhan terdiri dari: (a). Pengenalan kategorisasi bahan makanan sapi potong; (b). Kebutuhan nutrisi sapi potong berdasarkan berbagai penelitian; (c). Prinsip perhitungan sederhana kebutuhan makanan dalam ransum sapi potong; dan (d). Pengenalan dan pemaparan mengenai karakteristik dan manfaat Indigofera zollingeriana sebagai tanaman legum potensial untuk konsentrat.

Pada materi pengenalan kategorisasi bahan makanan ternak, masyarakat diberikan informasi mengenai komponen-komponen nutrisi ternak sesuai dengan berbagai teori dan silabus yang juga diajarkan kepada mahasiswa di Fakultas Peternakan Universitas Padja-djaran, seperti hijauan, konsentrat, dan bahan pakan tambahan (feed additives). Setelah materi pertama selesai, penyuluhan dilanjutkan dengan pengenalan prinsip penyusunan ransum diikuti pelatihan singkat mengenai perhitungan ransum sederhana yang berdasarkan kepada kebutuhan energi dalam berbagai fase hidup ternak, kebutuhan protein, kebutuhan lemak, kebutuhan mineral, kebutuhan vitamin, dan kebutuhan air. Nilai-nilai kebutuhan nutrisi ini berdasarkan kepada NRC (2001) dan berbagai jurnal hasil penelitian di bidang nutrisi ternak. Lebih spesifik lagi, dijelaskan mengenai masa transisi pada pembibitan sapi potong menyerupai dengan masa 
transisi pada sapi perah (Freetly dan Nienaber, 2006), di mana kebutuhan energi perlu disuplai dengan lebih baik, dikarenakan terdapat masa rentannya kekurangan energi akibat proses melahirkan, yang biasa disebut dengan kesetimbangan energi negatif (negative energy balancel NEB). Keseimbangan energi negatif telah dikaitkan dengan peningkatan terjadinya gangguan metabolisme (Grummer, 1993), penyakit menular (Collard $d k k$., 2000), penurunan reproduksi (Butler, 2003), inflamasi (Bionaz dkk., 2007), penurunan kekebalan tubuh (Mallard $d k k .$, 1998) (Mallard et al., 1998 dan stres oksidatif(Sordillo $d k k ., 2009$ ).

Pada tahap selanjutnya, dipaparkan keunggulan dan karakteristik Indigofera zollingeriana dan relevansinya sebagai bahan pakan alternatif penyusun ransum sapi potong. Dipaparkan pula bahwa beberapa penelitian telah mempelajari kandungan nutrisi Indigofera zollingeriana yang tinggi protein kasar (27,9\%), kalsium (0,22\%) dan fosfor (0,18\%; Akbarillah, dkk., 2002., Mayasari, dkk., 2018). Dengan kandungan protein yang relatif tinggi, maka potensi Indigofera zollingeriana menjadi bahan pakan alternatif hijauan pun penjadi tinggi. Selanjutnya, peternak juga dikenalkan dengan karakteristik Indigofera zollingeriana yang memiliki kemampuan produksi biomassa yang tinggi meskipun ditanam di tanah yang mengandung banyak garam dan memiliki tingkat salinitas yang tinggi (Nadir dkk., 2018), salah satu contohnya adalah wilayah dekat pantai seperti di Kabupaten Pangandaran. Di akhir penyuluhan ditambahkan pelatihan singkat pembuatan ransum komplit dengan menggunakan Indigofera zollingeriana. Pelatihan ini diberikan untuk memberikan gambaran kepada peternak mengenai dosis, cara pemberian dan penggunaannya dalam ransum komplit. Pelatihan ini dilakukan dengan pengenalan perhitungan ransum berdasarkan bahan kering ransum dan persentase bobot badan ternak.

Setelah pemaparan materi berakhir, sesi diskusi dimulai dan para peternak aktif bertanya, sebagian besar mengenai hal-hal teknis penanaman Indigofera zollingeriana. Berdasarkan hal itu, maka dilakukanlah pemaparan tambahan mengenai metode penyemaian bibit Indigofera zollingeriana, sehingga diharapkan para peternak dapat meningkatkan produksi biomassa Indigofera zollingeriana di wilayah Desa Kondangdjaja.

Kegiatan penyuluhan ini meningkatkan wawasan peternak mengenai tanaman legum Indigofera zollingeriana. Pada masa survei, sebagian besar peternak belum pernah mendengar tentang tanaman ini. Setelah penyuluhan ini dilaksanakan, peternak mampu mengenali karakteristik, manfaat, potensi, dan cara pengembang biakan Indigofera zollingeriana sebagai hijauan alternatif pengganti sebagian konsentrat. Hal ini diketahui dari pelaksanaan kuis (pre-test) dan diskusi (post-test) yang dilakukan setelah ceramah selesai, dengan pertanyaanpertanyaan mengenai karakteristik Indigofera zollingeriana yang mampu dijawab secara benar oleh sebagian besar peserta penyuluhan.
Faktor Pendukung

a. Rasa ingin tahu masyarakat akan Indigofera zollingeriana sangat tinggi sehingga antusias dalam mengikuti kegiatan penyuluhan dan menyerap informasi.

b. Dukungan pemerintah desa yang sangat baik, dibuktikan dengan kehadiran tokoh masyarakat dan perangkat desa yang ikut mendorong motivasi para peternak untuk menggali informasi lebih dalam mengenai potensi Indigofera zollingeriana sebagai bahan pakan alternatif untuk ransum sapi potong.

\section{Faktor Penghambat}

a. Ketersediaan Indigofera zollingeriana di daerah sekitar lokasi penyuluhan sangat minim. Hal ini menyebabkan eksposur peternak terhadap informasi mengenai Indigofera zollingeriana sangat rendah.

b. Terkait dengan ketersediaannya yang rendah, diperlukan waktu yang cukup lama dan lahan yang luas untuk membuat Indigofera zollingeriana di sekitar lokasi penyuluhan menjadi tanaman dengan produksi biomassa yang berkesinambungan. Hal ini berkaitan dengan produksi daun muda yang ideal sebagai bahan pakan setidaknya dibutuhkan waktu selama 60 hari sejak penanaman dengan pemupukan secara periodik ketika tanaman mencapai umur 30, 34, 38, dan 42 hari sejak masa tanam atau masa panen sebelumnya (Abdullah, 2014). Selain itu, untuk pembibitan diperlukan waktu selama 6 minggu dan persemaian dibutuhkan waktu setidaknya 4 minggu (Abdullah, 2014). Sejalan dengan itu, jarak ideal antar individu tanaman adalah 1,5 meter $\times 1$ meter, dengan total populasi 6.600 individu tanaman per hektar lahan (Abdullah, 2014). Dengan kata lain, kepadatan ideal tanaman adalah 0,6 tanaman per $\mathrm{m}^{2}$ lahan. Oleh karenanya, diperlukan fase pendampingan setelah fase introduksi ini, demi mewujudkan produksi biomassa Indigofera zollingeriana yang berkesinambungan. Tidak jauh dari lokasi penyuluhan terdapat satu tempat produksi biomassa dan pembibitan Indigofera zollingeriana yang dikelola oleh perusahaan yang didampingi oleh para tenaga ahli. Hal ini pula yang menjadikan motivasi bagi peternak untuk dapat memproduksi tanaman ini secara mandiri dengan potensi yang dimiliki.

\section{SIMPULAN}

Kegiatan penyuluhan mengenai potensi Indigofera zollingeriana sebagai bahan pakan alternatif pengganti hijauan berhasil dilaksanakan. Dengan antusiasme peternak peserta penyuluhan, kegiatan penyuluhan dapat meningkatkan wawasan peternak peserta penyuluhan, tercermin dari berhasilnya peternak untuk menjelaskan potensi manfaat dan proses perkembangbiakan Indigofera zollingeriana sebagai salah satu hijauan sumber protein sebagai pengganti sebagian konsentrat untuk sapi potong. 


\section{UCAPAN TERIMA KASIH}

Penulis mengucapkan terima kasih yang sebesar-besarnya kepada Pimpinan Fakultas Peternakan Universitas Padjadjaran yang telah memberikan izin kepada kami untuk menyelenggarakan penyuluhan. Penulis juga mengucapkan terima kasih kepada Kelompok Peternak Putra Nusa dan perangkat pemerintah Desa Kondangdjaja yang telah memberikan kesempatan kepada tim penulis untuk melakukan kegiatan penyuluhan pengenalan potensi dan manfaat legum Indigofera zollingeriana sebagai hijuan alternatif sumber protein pengganti sebagian konsentrat sapi potong.

\section{DAFTAR PUSTAKA}

Abdullah, L. 2014. Prospektif Agronomi dan Ekofisiologi Indigofera zollingeriana sebagai Tanaman Penghasil Hijauan Pakan Berkualitas Tinggi. Pastura 3:79-83.

Akbarillah T, D Kaharudin, \& Kususiyah. 2002. Kajian tepung daun Indigofera sebagai supplemen pakan terhadap produksi dan kualitas telur. Laporan Penelitian Universitas Bengkulu: Lembaga Penelitian, Universitas Bengkulu.

Bertoni, G., E. Trevisi, \& R. Lombardelli. 2009. Some new aspects of nutrition, health conditions and fertility of intensively reared dairy cows. Ital. J. Anim. Sci. 8:491-518. doi:10.4081/ijas.2009.491. http://www. tandfonline.com/doi/full/10.4081/ijas.2009.491.

Bionaz, M., E. Trevisi, L. Calamari, F. Librandi, A. Ferrari, \& G. Bertoni. 2007. Plasma Paraoxonase, Health, Inflammatory Conditions, and Liver Function in Transition Dairy Cows. J. Dairy Sci. 90:17401750. doi:10.3168/jds.2006-445. http://dx.doi. org/10.3168/jds.2006-445.

BPS Jabar. 2017. Jumlah Ternak Menurut Kabupaten/ Kota dan Jenis Ternak di Provinsi Jawa Barat 2016. https:/jabar.bps.go.id/statictable/2018/03/20/426/-jumlah-ternak-menurut-kabupaten-kota-dan-jenisternak-di-provinsi-jawa-barat--ekor---2016.html.

Butler, W.R. 2003. Energy balance relationships with follicular development, ovulation and fertility in postpartum dairy cows 83:211-218.

Collard, B.L., P.J. Boettcher, J.C.M. Dekkers, D. Petitclerc, \& L.R. Schaeffer. 2000. Relationships Between Energy Balance and Health Traits of Dairy Cattle in Early Lactation. J. Dairy Sci. 83:2683-2690. doi:10.3168/jds.S0022-0302(00)75162-9. http:// dx.doi.org/10.3168/jds.s0022-0302(00)75162-9.

Freetly, H.C., \& J.A. Nienaber. 2006. Partitioning of energy during lactation of primiparous beef cows $12157-$ 2162. doi:10.2527/jas.2005-534.
Grummer, R.R. 1993. Etiology of Lipid-Related Metabolic Disorders in Periparturient Dairy Cows. J. Dairy Sci. 76:3882-3896. doi:10.3168/jds.S00220302(93)77729-2. http://dx.doi.org/10.3168/jds. s0022-0302(93)77729-2.

Hassen, A., N.F.G. Rethman, \& Z. Apostolides. 2006. Morphological and agronomic characterisation of Indigofera species using multivariate analysis. Trop. Grasslands 40:45-59http://citeseerx.ist.psu.edu/ viewdoc/d?doi=10.1.1.581.4132\&rep=rep1\&type $=$ pdf.

Hernaman, I., A. Budiman, \&A.R. Tarmidi. 2018. Perbaikan Mutu Ransum Sapi Potong Melalui Pemberian Konsentrat Berbasis Pakan Lokal di Purwakarta. Dharmakarya J. Apl. Ipteks untuk Masy. 7:1-5. doi:ISSN 14105675.

Mallard, B.A., J.C. Dekkers, M.J. Ireland, K.E. Leslie, S. Sharif, C. Lacey Vankampen, L. Wagter, \& B.N. Wilkie. 1998. Alteration in Immune Responsiveness During the Peripartum Period and Its Ramification on Dairy Cow and Calf Health. J. Dairy Sci. 81:585-595. doi:https://doi.org/10.3168/jds.S00220302(98)75612-7. http://www.sciencedirect.com/ science/article/pii/s0022030298756127.

Mayasari, N., Lia, B. M. S, \& Endang, Y. 2018. Identifikasi biomarker patofisiologi: Penggunaan Mineral Anorganik dan Indigofera zollingerana untuk Peningkatan Produktivitas, Reproduksi dan Kekebalan Alami Sapi Perah. Laporan Akhir Riset Kompetensi Dosen Unggulan Universitas Padjadjaran.

Nadir, M., M.J. Anugrah, \& P.I. Khaerani. 2018. Salt Salinity Tolerance on Nursery of Indigofera zollingeriana Salt Salinity Tolerance on Nursery of Indigofera zollingeriana. IOP Conf. Ser. Earth Environ. Sci. 156. doi:10.1088/17551315/156/1/012027. https://iopscience.iop.org/ article/10.1088/1755-1315/156/1/012027/pdf.

Nurhayu, A., \& D. Pasambe. 2014. Indigofera sebagai Substitusi Hijauan pada Pakan Sapi Potong di Kabupaten Bulukumba Sulawesi Selatan. Pages 52-56 in Seminar Nasional Peternakan 2, Fakultas Peternakan Universitas Hasanuddin Makassar.

Salgueiro, M.J., M. Zubillaga, A. Lysionek, G. Cremaschi, C.G. Goldman, R. Caro, T. De Paoli, A. Hager, R. Weill, \& J. Boccio. 2000. Zinc status and immune system relationship. Biol. Trace Elem. Res. 76:193205. doi:10.1385/BTER:76:3:193.

Salman L. B., I. Hernaman, I. Sulistiawati, M. Maisarah, H. Yuhani, R. Salim, \& A. Arfiana. 2017. Penggunaan Indigofera zollingeriana untuk menggantikan konsentrat dalam ransum sapi perah. Laporan Penelitian Hibah Internal Unpad. 
Setiyatwan, H., E. Harlia, \& D. Rusmana. 2018. Budidaya dan Aplikasi Teknologi Pengolahan Duckweed (Lemna sp.) sebagai Pakan Konsentrat serta Penggunaannya untuk Ternak Itik di Desa Sidomulyo dan Desa Wonoharjo Kecamatan Pangandaran Kabupaten Pangandaran. J. Pengabdi. Kpd. Masy. 2:1-5http://jurnal.unpad.ac.id/pkm/ article/view/16536/8038.

Sordillo, L.M., G.A. Contreras, \& S.L. Aitken. 2009. Metabolic factors affecting the inflammatory response of periparturient dairy cows y 10:53-63. doi:10.1017/S1466252309990016.

Susilawati, I., N.P. Indriani, \& U.H. Tanuwiria. 2014. Inovasi Teknologi Pakan Sapi Potong Berbasis
Sumberdaya Lokal di Desa Pasirbungur dan Purwadadi Barat Kecamatan Purwadadi Kabupaten Subang. Dharmakarya J. Apl. Ipteks untuk Masy. 3:9-12. doi:ISSN: 14105675.

Tanaka, S., E. Takahashi, T. Matsui, \& H. Yano. 2001. Zinc Promotes Adipocyte Differentiation in vitro. AsianAustralasian J.Anim. Sci. 14:966-969. doi:10.5713/ ajas.2001.966.

Tarigan, A., \& Ginting, S. P. 2011. Pengaruh taraf pemberian Indigofera sp. terhadap konsumsi dan kecernaan pakan serta pertambahan bobot hidup kambing yang diberi rumput Brachiaria ruziziensis. JITV, 16, 25-32. 